\title{
Assessing "Results-Based" Payment Determinants in Forest Carbon Emission Reduction Initiatives: Case of Forest Carbon Projects in Cameroon
}

\author{
Eugene L Chia ${ }^{1,2}$, Augustin Corin B Bi Bitchick ${ }^{3,4}$, Didier Hubert ${ }^{5}$, Mirrande M Azai ${ }^{6}$ \& Maxime M Nguemadji ${ }^{7}$ \\ ${ }^{1}$ FOKABS INC, 955 Rotary Way, K1T 0L2 Ottawa ON, Canada \\ ${ }^{2}$ Centre for Environmental Studies, University of Pretoria, South Africa \\ ${ }^{3}$ PNDP, MINEPAT, Yaoundé, Cameroon \\ ${ }^{4}$ Faculty of Economics and Management Sciences, University of Dschang, Cameroon \\ ${ }^{5}$ Eco-Consult, C/o GIZ/PFE, BP 7814, Yaoundé, Cameroon \\ ${ }^{6}$ FASA, University of Dschang, Cameroon \\ ${ }^{7}$ REDD+ National Coordination, MINEPDED, Yaoundé, Cameroon \\ Correspondence: Eugene L Chia, Centre for Environmental Studies, University of Pretoria, South Africa. Tel: 00- \\ 2376-7805-7925. E-mail: lohchia@gmail.com
}

Received: January 20, 2021

Accepted: February 10, 2021

Online Published: March 29, 2021

doi:10.5539/jsd.v14n3p45

URL: https://doi.org/10.5539/jsd.v14n3p45

\begin{abstract}
The international community has acknowledged the critical role of results-based avoided deforestation and forest degradation, sustainable management of forest, conservation and enhancement of carbon stocks (REDD+) activities in curbing climate change. However, ensuring that REDD+ programs and projects deliver carbon and non-carbon results, remains a challenge. This paper analyses results-based determinants in REDD+ projects in Cameroon. Experiences from these projects are expected to inform the design and implementation of sustainable and effective REDD + projects. It draws on data collected from feasibility study reports, project design documents, project evaluation reports and the opinions and perspectives of 86 REDD+ stakeholders. Findings indicate that projects employed a combination of incentives, disincentives and enabling measures towards achieving the intended REDD+ results. However, none of the projects proposed conditional incentives (direct payments) to land owners and users, the key innovation brought by REDD + . Despite the fact that these projects are branded REDD+ projects, they offer little or no experiences on the relationship between REDD + payments and carbon and noncarbon outcomes. Achieving results from REDD + projects depend on how effective choices are made by stakeholders in relation to the type of instruments/interventions and the location of projects, and the ability to make choices further depends on the technical capacity of stakeholders. Thus, the capacity of stakeholders to be involve in REDD+ project design and implementation should be strengthened, in order for them to better appraise the results-based requirements of REDD+.
\end{abstract}

Keywords: climate change, mitigation, REDD+ projects, Cameroon, Congo Basin

\section{Introduction}

Tropical deforestation and forest degradation play a critical role as a driver of climate change through anthropogenic carbon dioxide emissions. The avoided deforestation and forest degradation, sustainable management of forest, conservation and enhancement of carbon stocks (REDD+) approach was put forward to counteract these emissions as underscored in the post-2020 climate change Paris agreement. (UNFCC, 2015). Article 5 of the agreement encourages parties to consider incentivizing efforts to achieve both carbon and noncarbon objectives of REDD+ (UNFCC, 2015; Katerere \& Kalame, 2015]. REDD+ differs from previous conservation instruments because of its results-based approach, in which payments are knotted to demonstrated reduction in carbon emissions (Simonet, Duchelle, Resosudarmo, Subervie, \& Wunder, 2018a).

It was generally acknowledged that it will take time, consultations, research and experience for REDD+ countries to respond to the exigencies of REDD + design and implementation. To this effect, the United Nations Framework 
Convention on Climate Change invited the international community to promote REDD + through preparatory support such as capacity building and demonstration projects (Cerbu, Swallow \&Thompson, 2011). Understanding project level realities required to achieve REDD+ objectives is necessary to inform both national REDD+ policies and the literature on REDD + design and implementation. Hundreds of REDD+ projects have been designed and are being implemented across many tropical countries, supported by international and national agencies. REDD+ projects entail 'activities implemented in a particular sub-national region or unit with the intention of reducing deforestation and forest degradation in that particular area' (Cerbu et al., 2014). While their activities may differ, these projects share a common objective i.e., to mitigate climate change (Simonet et al., 2018a; Cerbu et al., 2011), and to document and disseminate experiences (De Sassi et al., 2014). Lessons and experiences will help REDD+ countries finalize national strategies, develop and implement sub-national and national results-based payment projects. Efforts and progress have been made to document and disseminate lessons and experiences from demonstration activities in different countries and regions (Simonet et al., 2018a; Duchelle et al., 2018a; Duchelle, Simonet, Sunderlin \& Wunder, 2018b; Sunderlin et al., 2014a; Sunderlin et al., 2014b). However, researchers and practitioners are still requesting for further research as far as generating information on lessons learned is concerned (Simonet et al., 2018a; Duchelle, De Sassi, Sills \& Wunder, 2018c). This is the major point of departure for this paper. Furthermore, the paper is relevant to REDD+ countries that are planning to respond to their post2020 climate change mitigation commitments through results-based emission reduction projects and programs.

More specifically, Cameroon has underscored the important role of REDD+ in achieving its post-2020 climate change mitigation commitments, through the development of strategic results-based sectoral and cross-sectoral programs and projects (MINEPDED, 2018; Chia, Hubert, Carudenuto \& Sene; 2019). REDD+ project activities are being implemented in the 5 agroecological zones and these projects are expected to feed national policy processes with lessons learned and experiences (MINEPDED, 2012). However, no study has explicitly examined ongoing demonstration initiatives registered in the national REDD+ program and project pipeline, for example, in terms of assessing the consideration of results-based determinants in the design and early implementation of these REDD + projects, thus the overall objective of this paper. Some of the experiences and information - even if far from perfect, enables us to make preliminary analysis that are relevant to move the REDD+ agenda forward. Specifically, this paper sets out to analyse some determinants of results in the design and early implementation phases of REDD+ projects in Cameroon, in terms of (i) the type of instruments and/or interventions being implemented to achieve results and (ii) the pre-conditions for selecting project locations. The next section unpacks the two proposed determinants of results in REDD+ projects as the conceptual framework. The methodology, results and analysis, discussion and conclusion then follow subsequently.

\section{Conceptual Framework}

The results-based approach of REDD+, distinguishes it from other previous conservation initiatives, where payment is contingent on results which are in practice evaluated as reduced emissions (Angelsen, Hermansen, Rajão \&Van Der Hoff, 2018). The results-based potential of REDD+ projects can be influenced by a wide range of factors (Duchelle et al., 2018a; Simonet et al., 2018a); this is due to the fact that REDD+ is expected to respond to multiple and at times contradictory objectives and outcomes. In this paper, two categories of factors are considered in terms of influencing a project's/program's capacity to deliver results. First, the type of instruments/interventions (Duchelle et al., 2018a; Simonet et al., 2018a); and second the suitability of a project location (Pasgaard \& Mertz, 2016). The proposed determinants together with their sub-elements are not exhaustive, however, they provide a good basis for analysis. Furthermore, they were selected among others that exist in the REDD+ literature due to their direct interaction and focus at the project level in relation to project design and implementation. This study acknowledges the existence of other determinants that are external to a projects' environment such as the role of state institutions (Atela, Minang, Quinn \& Duguma 2015 ), and national and international governance structures that influence the effectiveness and efficiency of REDD+ implementation (Vatn \& Vedeld, 2011).

\subsection{Types of REDD+ Interventions/Instruments}

REDD + objectives can be achieved through distinct instruments/interventions that can be grouped as incentives, enabling measures and disincentives (Duchelle et al., 2018a; Simonet et al., 2018a; Börner et al., 2018). Incentives (cash or non-cash) based instruments refer to approaches that provide compensation to landowners and land users for implementing actions that results to maintaining or enhancing carbon stocks (Börner et al., 2018). Incentives have the objective of inducing change in the behavior of land users in order to achieve REDD+ goals, compensate them for any loss ensuing from the changes, and direct them to more sustainable production and the improvement of their livelihoods (Simonet et al., 2018a). They can be conditional and non-conditional. Conditional incentives include interventions that are conditioned for example in exchange for benefits by the adoption of specific practices 
(reforestation, agroforestry and forest protection), with the payment for ecosystem services (PES) model being the most tested and used example across the globe (Simonet et al., 2018a). Non-conditional incentives include technical assistance, distribution of agriculture inputs (seeds and fertilizers), introduction of improved cook stoves etc (Simonet et al., 2018a).

Enabling measures aim to create suitable conditions for REDD+ projects to function in a way to ensure positive outcomes for both carbon and community well-being. Some of these measures include local environmental education, Free Prior and Inform Concern (FPIC) considerations, capacity building and activities aimed at clarifying ownership, access rights over forest, trees and carbon (Duchelle et al., 2018a; Simonet et al., 2018a)

Disincentives are instruments that restrict access to forest and/or conversion of forest land to agriculture land, and are important for reducing deforestation and forest degradation. These can include the enforcement of forest protection laws and regulations (for example in countries having forest codes), monitoring (for example by communities or forest administration) or sanctioning through fines (Duchelle et al., 2018a; Simonet et al., 2018a)

\subsection{Suitability of Project Location}

REDD+ project locations should comply with the following conditions to ensure that carbon and non-carbon outcomes are delivered efficiently, effectively and equitably.

\subsubsection{Deforestation Threat}

The threat of deforestation is important in determining project location. According to Pasgaard and Metz, (2016) sites selected for REDD+ activities should experience a high threat to enable a reduction in emissions eligible for enough carbon credits compared with agreed reference levels.

\subsubsection{Relatively Low Opportunity Cost}

According to Mertz et al. (2012) and Newton, Nichols, Endo \& Peres (2012), if opportunity cost is too high, carbon investments will be in jeopardy because considerably high payments will be needed to compensate land users for forgone opportunities.

\subsubsection{Local Willingness to Involve in REDD+ Activities}

Local willingness to be part of REDD+ projects is required to ensure efficient and effective carbon emission reductions in addition to non-carbon benefits. It is indicated that limited or no involvement of local communities for example in project design and implementation is a big driver of non-permanence and leakage, and a threat to project sustainability (Cromberg, Duchelle \& Rocha, 2014). The need to get local people involved in REDD+ design and implementation is explicitly indicated in the Cancun safeguards of the climate change convention and in other REDD+ safeguard standards (Moss \& Nussbaum; UNFCCC, 2011).

\subsubsection{Large Forest Areas}

Large forest areas are preferred in terms of performance because small and fragmented forests are not suited to guarantee large emissions that is relevant for national and global emission reduction commitments. Small forest areas could push projects to record high transaction costs, drive leakage with high possibilities to undercut REDD+ additionality (Balooni \& Lund, 2014).

\subsubsection{Non-Carbon Benefit Potentials}

REDD+ project locations should be chosen based on their potential to deliver non-carbon benefits. The Non-carbon benefit of REDD+ initiatives is underscored in article 5 of the Paris Agreement (UNFCC, 2015), and they include poverty alleviation, biodiversity gains, improve land tenure, climate change adaptation etc. (Katerere \& Kalame, 2015). Hett, Heinimann, Epprecht, Messerli \& Hurni, 2012) assert that the spatial combination of carbon stocks and poverty should be an important factor to consider when selecting project sites. This paper draws on these factors to analyze the design and early implementation phases of REDD + projects, in which findings are expected to inform the design and implementation of effective REDD+ initiatives.

\section{Methodology}

\subsection{Location and Context of Case Study Projects}

The six projects involved in this study are located in 5 different agroecological zones (AEZ) of Cameroon (Figure 1). They are the first set of projects that entered the national REDD+ project and program pipeline in Cameroon, following the validation of their Project Idea Notes and Project Design Documents by the National REDD+ Steering Committee (Table 1). The steering committee at the moment is the highest institutional and decisionmaking authority that provides general orientation on the implementation of REDD+ in Cameroon. 


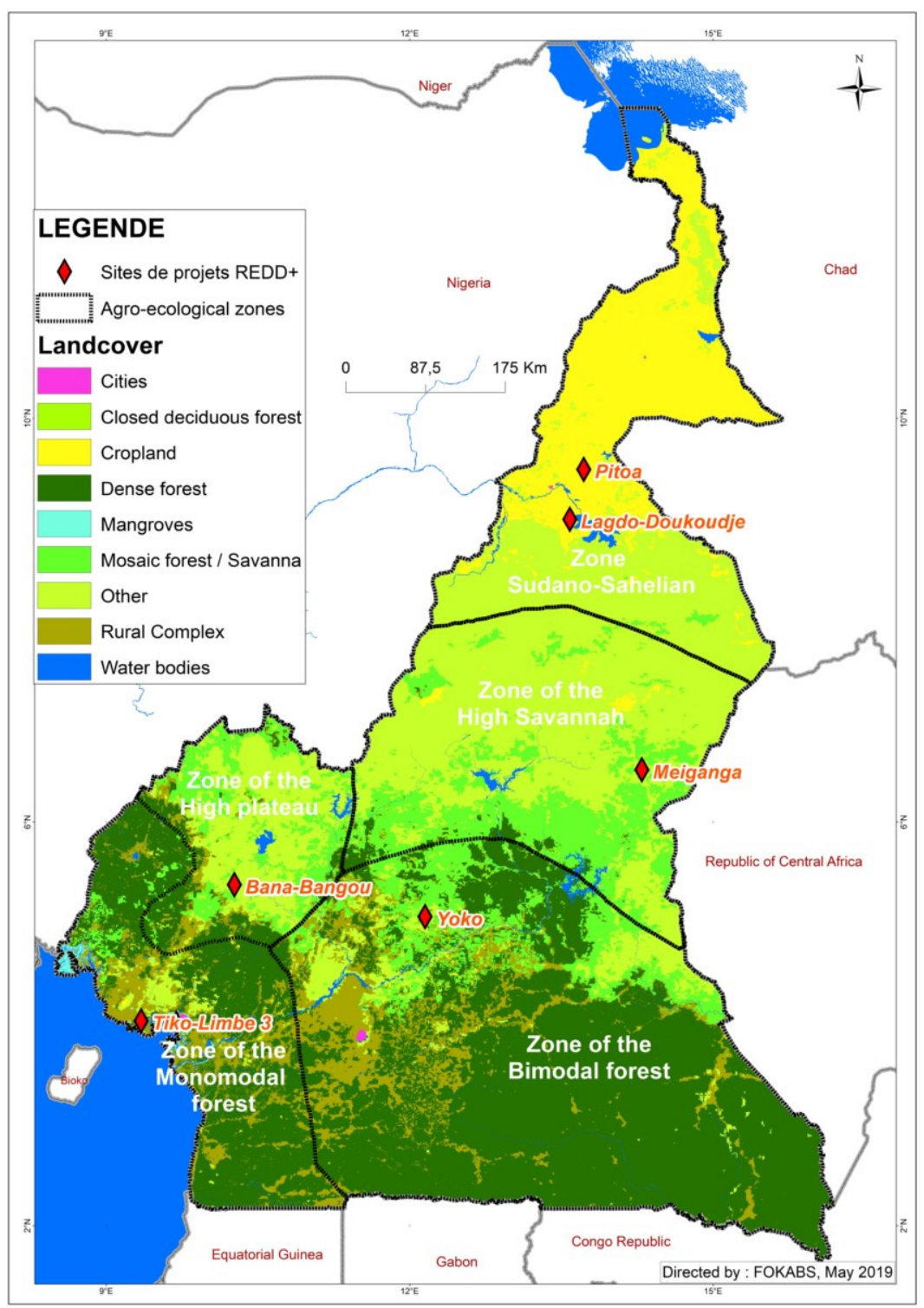

Figure 1. Map showing of project locations across the national territory 
Table 1. Profile of case study projects

\begin{tabular}{|c|c|c|c|}
\hline Project title & $\begin{array}{l}\text { Project proponent } \\
\text { (s)/AEZ }\end{array}$ & $\begin{array}{l}\text { Estimated carbon } \\
\text { accounting area (ha) }\end{array}$ & $\begin{array}{l}\text { Estimated } 30 \text { years } \\
\text { emission reduction }\left(\mathrm{tCO}_{2 \mathrm{e}}\right)\end{array}$ \\
\hline $\begin{array}{l}\text { Project for the reduction of deforestation and } \\
\text { forest degradation in the Bangante-Bana-Bangou } \\
\text { intercommunal massif forest (BBB) }\end{array}$ & $\begin{array}{l}\text { Bangangte Council; } \\
\text { Bana Council; Bangou } \\
\text { Council/ } \\
\text { Western Plateau }\end{array}$ & 4800 & 1927844 \\
\hline $\begin{array}{l}\text { Project for the conservation of the Ouro } \\
\text { Doukoudje massif forest and the reforestation of } \\
\text { the west bank of lake Lagdo (Lagdo) }\end{array}$ & $\begin{array}{l}\text { Lagdo Council/Sudano } \\
\text { Sahelian }\end{array}$ & 6015,21 & 760545 \\
\hline $\begin{array}{l}\text { Project to reduce the degradation and restoration } \\
\text { of vegetation cover in the Pitoa Council agro- } \\
\text { sylvo-pastoral area (Pitoa) }\end{array}$ & $\begin{array}{l}\text { Pitoa Council/Sudano } \\
\text { Sahelian }\end{array}$ & 9408,8 & 645033 \\
\hline $\begin{array}{l}\text { Project for the Reduction of Tiko-Limbe III } \\
\text { mangrove deforestation and degradation through } \\
\text { integrated sustainable mangrove and associated } \\
\text { coastal forest management (Tiko-Limbe) }\end{array}$ & $\begin{array}{l}\text { Tiko Council/Unimodal } \\
\text { rainfall }\end{array}$ & 10011 & 4905074 \\
\hline $\begin{array}{l}\text { Project for the protection of the Yoko council } \\
\text { forest through the implementation of agro-sylvo- } \\
\text { pastoral activities (Yoko) }\end{array}$ & $\begin{array}{l}\text { Yoko Council/Bimodal } \\
\text { rainfall }\end{array}$ & 29500 & 4512970,8 \\
\hline $\begin{array}{l}\text { Project for the Protection of the lokoti woodland } \\
\text { area in the Meiganga Council through the } \\
\text { adoption of alternative activities in peripheral } \\
\text { areas (Meiganga) }\end{array}$ & $\begin{array}{l}\text { Meiganga Council/High } \\
\text { Guinea Savannah }\end{array}$ & 63252 & 3703162 \\
\hline
\end{tabular}

Sources: PNDP, 2017a; PNDP, 2017b; PNDP, 2017c; PNDP, 2017d; PNDP, 2017e; PNDP, 2018a

\subsection{Data Collection and Analysis}

The paper draws on project documents, literature and the opinions and perspectives of REDD + stakeholders. Guided by the factors presented in the conceptual framework, different types of documents related to the projects were examined. They include project idea notes, feasibility study reports and project design document, reports of review and validation workshops, mid-term implementation evaluation meeting reports etc. The opinions and perspectives of 86 stakeholders were collected through face-to-face interviews as part of a master's thesis project. Stakeholders were selected based on their participation in the different stages of the REDD + project development process, as indicated in the list of participants of the technical review and validation workshops and other consultation meetings. Interview request were sent to stakeholders following the email addresses in the participant list and of all the stakeholders contacted, 118 indicated their availability, but only 86 finally participated in the interviews. The 86 stakeholders were comprised of individuals from the state forest and environment administrations, civil society organizations, project proponents and project managers.

The questionnaire had a combination of likert-scale statement questions (evaluating levels of agreement/satisfaction) and open-ended questions. Responses were anonymous allowing respondents to air their personal opinions and perspectives on sensitive matters. A likert scale was used to rate their responses, ranging from 1 - meaning strongly disagree - to 5 - meaning strongly agree or ranging from 1 - meaning very satisfied - to 5 - not very satisfied. Responses to five stances developed from the five conditions determining choice of project locations, were used to assess, more generally, stakeholders' opinions related to project locations. Opinions condition the behavior, engagement and compliance of actors in the design and implementation of strategies and activities (Carmenta, Zabala, Daeli \& Phelps, 2017; Bennett, 2016). 
In addition, some authors have been involved in the REDD+ policy and strategy elaboration process in Cameroon and have been part of the development process of the case study projects, from project identification, to design and implementation. Some of the authors further participated in the field monitoring and evaluation visits and in the first quarter project evaluation meeting held in Yaoundé, in July 2018. This provided capacity to better analyze project documents and the identification of latent factors that contributed to the choice of project locations.

\section{Results and Analysis}

The results are presented and analyzed in two sub-sections. First, the different instruments/interventions employed in the case study projects are presented and analyzed bringing in evidence from projects in different countries. This is followed by the trends in stakeholder opinions and perspectives on project location regarding the suitable factors of REDD+ project location, as well as the latent factors.

\subsection{REDD+ Instruments/Interventions Employed in Projects}

The findings of the different instruments proposed by project proponents to achieve carbon and livelihood outcomes in the case study projects are presented in table 2 .

\subsubsection{Incentive Instruments/Interventions}

Concerning the incentive instruments/interventions, results indicate that none of the projects have been able to propose conditional incentives, for example making direct compensation to landholders or communities for the efforts they are making to ensure and monitor activities that will conserve and enhance carbon stocks. PES is the most widely used conditional incentive mechanism in the context of forest carbon projects where payment contracts are made with landholders and managers, to make payments on results achieve after define periods (Simonet et al., 2018b; Salzman, Bennett, Carroll, Goldstein \& Jenkins, 2018; Ezzine-De-Blas, Wunder, RuizPérez \& Del Pilar Moreno-Sanchez, 2016). Reports from location specific case studies indicate that PES as a conditional incentive was able to deliver forest conservation/protection and livelihood objectives. For example, in Uganda, a carbon forestry project offering individual payments to smallholders in return for forest conservation and tree planting was able to score positive avoided deforestation results and tree cover increase (Jayachandran, De Laat, Lambin, Stanton, Audy \& Thomas, 2017). Positive results in terms of forest cover and biomass gains were also recorded in some project sites in Nepal (Pandey, Cockfield \& Maraseni, 2016). India (Poffenberger, 2015), and Brazil (Simonet, Subervie, Ezzine-De-Blas, Cromberg, \& Duchelle, 2018b). In a case study in Nepal, REDD+ payments on the one hand contributed in reducing income inequality, while on the other hand created social tension among households (Shrestha, Shrestha, \& Bawa, 2017). At the moment, there is no well documented experience on PES application in Cameroon, however it is an instrument that needs to be stressed and used in order to make contributions toward achieving results from planned forest carbon emission reduction initiatives.

Table 2. Instruments and interventions employed in case study projects

\begin{tabular}{|c|c|c|c|c|}
\hline Project & $\begin{array}{l}\text { Conditional } \\
\text { incentives }\end{array}$ & Non-conditional incentives & Enabling measures & Disincentives \\
\hline BBB & $\mathrm{X}$ & $\begin{array}{l}\text { - Technical and material assistance } \\
\text { to increase agriculture productivity } \\
\text { - Construction of livestock } \\
\text { infrastructure for Bororo } \\
\text { communities } \\
\text { - Construction of local leisure and } \\
\text { touristic infrastructure }\end{array}$ & $\begin{array}{l}\text { - Creation of multi-actor } \\
\text { platform for dialogue and } \\
\text { conflict management between } \\
\text { land users } \\
\text { - Capacity building in } \\
\text { developing viable micro } \\
\text { livestock projects } \\
\text { - Capacity building in the } \\
\text { amelioration of agriculture } \\
\text { productivity }\end{array}$ & $\begin{array}{l}\text { - Creation of forest surveillance } \\
\text { and monitoring committees } \\
\text { - Elaboration and implementation } \\
\text { of a Simple Management Plan in } \\
\text { accordance with the legal } \\
\text { framework }\end{array}$ \\
\hline Lagdo & $\mathrm{X}$ & $\begin{array}{l}\text { - Distribution and use of improve } \\
\text { cook stoves } \\
\text { - Promotion of alternative income } \\
\text { generating activities } \\
\text { - Rehabilitation of transhumance } \\
\text { corridors and water-points for } \\
\text { livestock } \\
\text { - Construction of solar boreholes }\end{array}$ & $\begin{array}{l}\text { - Creation of multi-actor } \\
\text { platform for dialogue and } \\
\text { conflict management between } \\
\text { land users } \\
\text { - Capacity building in the } \\
\text { construction of improve cook } \\
\text { stoves and fish smoking ovens }\end{array}$ & $\mathrm{X}$ \\
\hline
\end{tabular}




\begin{tabular}{|c|c|c|c|c|}
\hline & & $\begin{array}{l}\text { - Construction of improve ovens for } \\
\text { fish smoking } \\
\text { - Promotion of fish farming through } \\
\text { the construction of ponds }\end{array}$ & & \\
\hline Pitoa & $X$ & $\begin{array}{l}\text { - Rehabilitation of transhumance } \\
\text { corridors and water-points for } \\
\text { livestock } \\
\text { - Technical assistance to } \\
\text { sylviculture activities } \\
\text { - Support to the creation of tree } \\
\text { nurseries and plantations for wood } \\
\text { energy } \\
\text { - Distribution and use of improve } \\
\text { cook stoves } \\
\text { - Technical assistance to } \\
\text { agroforestry activities } \\
\text { - Construction of boreholes }\end{array}$ & $\begin{array}{l}\text { - Capacity building in agro- } \\
\text { sylvo-pastoral techniques } \\
\text { - Capacity building in the } \\
\text { construction of improve cook } \\
\text { stoves }\end{array}$ & $\mathrm{X}$ \\
\hline $\begin{array}{l}\text { Tiko- } \\
\text { Limbe }\end{array}$ & $\mathrm{X}$ & $\begin{array}{l}\text { - Distribution of energy efficient } \\
\text { cook stoves } \\
\text { - Construction and rehabilitation of } \\
\text { tourism infrastructure } \\
\text { - Promotion of pilot reforestation } \\
\text { and regeneration activities }\end{array}$ & $\begin{array}{l}\text { - Elaboration of a land use plan } \\
\text { addressing access and resource } \\
\text { use conflicts } \\
\text { - Creation of steering } \\
\text { committees and community } \\
\text { management committees } \\
\text { - Capacity building in } \\
\text { agriculture intensification } \\
\text { techniques } \\
\text { - Environmental education on } \\
\text { the importance of conserving } \\
\text { mangrove ecosystems }\end{array}$ & $X$ \\
\hline Yoko & $\mathrm{X}$ & $\begin{array}{l}\text { - Construction of fishponds and } \\
\text { warehouses } \\
\text { - Reorganization of women groups } \\
\text { into micro enterprises for the } \\
\text { valorization of non-timber forest } \\
\text { products } \\
\text { - Construction of livestock water } \\
\text { points } \\
\text { - Material assistance to farmers, bee } \\
\text { farmers, cattle breeders, } \\
\text { reforestation activities etc. }\end{array}$ & $\begin{array}{l}\text { - Capacity building of farmers } \\
\text { organizations improve agro- } \\
\text { pastoral practices } \\
\text { - Capacity building of farmers } \\
\text { organizations in beekeeping } \\
\text { and fish farming }\end{array}$ & $\begin{array}{l}\text { - Elaboration of Council Forest } \\
\text { management plan in accordance } \\
\text { with the legislative framework } \\
\text { - Enhance forest monitoring by } \\
\text { trained eco-guards in accordance } \\
\text { with the management plan } \\
\text { - Elaboration of Sustainable Land } \\
\text { use Plan in accordance with the } \\
\text { national legal framework }\end{array}$ \\
\hline Mieganga & $\mathrm{X}$ & $\begin{array}{l}\text { - Technical and material assistance } \\
\text { to improve Non Timber Forest } \\
\text { Product value chain, reforestation, } \\
\text { agroforestry } \\
\text { - Construction and distribution of } \\
\text { improve cook stoves } \\
\text { - Construction of boreholes }\end{array}$ & $\begin{array}{l}\text { - Capacity building of farmers } \\
\text { and pastoralist } \\
\text { - Capacity building on fire } \\
\text { management techniques }\end{array}$ & $\begin{array}{l}\text { - Elaboration of natural resources } \\
\text { management plan } \\
\text { - Forest monitoring by trained } \\
\text { eco-guards in accordance with } \\
\text { management plan }\end{array}$ \\
\hline
\end{tabular}

$\mathrm{X}=$ Absence of instrument and intervention. Sources: PNDP, 2017a; PNDP, 2017b; PNDP, 2017c; PNDP, 2017d; PNDP, 2017e; PNDP, 2018a.

Incentives proposed in case study projects are dominated by non-conditional interventions that may have direct and/or indirect implications on forest and biomass dynamics and the enhancement of livelihoods assets (table 2). Simonet et al. (2018a) mention the difficulty to evaluate the impacts of non-conditional incentives on results due to the absence of robust impact analysis methods dealing directly with non-conditional interventions. 
Notwithstanding, non-conditional interventions has resulted to an increase in carbon stocks in projects implemented in some other countries such as Nepal, where results were attributed to the use of improve cooking stoves (Pandey et al., 2016), and in India, attributed to fire control and the use of improve cooking stoves (Poffenberger, 2015). It should be noted that in the two cases mentioned, other interventions such as disincentives and enabling measures were employed as well, despite the fact that the results pointed to the use of improve cooking stoves as the main driver of the slight increase in biomass (Simonet et al., 2018a).

\subsubsection{Disincentives and Enabling Measures}

The case study REDD+ projects are also comprised of hybrids of enabling measures and disincentives, apart from three projects where disincentives are not proposed (Table 2). This is due to the fact that the carbon accounting areas of the three projects have forest areas that are not at the moment in compliance with the forest legislative framework. Thus, applying disincentive interventions such as the enforcement of forest regulations and sanctioning through fines could abuse local rights and fuel conflicts. According to observations from one of the authors during a field visit, disagreement between communities and project proponents occurred in these three project sites in relation to the location of reforestation areas agreed upon during community consultations. Thus, for each of the three projects, some reforestation sites were relocated at the start of project implementation to stay within the size of the carbon stocks accounting area and projected results. This confusing situation was attributed to the insufficient and ineffective consultations carried out during project design as stipulated by the REDD+ FPIC guidelines of Cameroon. As of now, approaches to assess the effectiveness of these instruments on carbon results in the long-term have not yet been designed for the ongoing case study projects. Effectiveness of the projects in this context involves the ability of projects to avoid leakage, ensure additionality and permanence (Vatn \& Vedeld, 2011). However, the complexity and the lack of robust approaches to evaluate the effectiveness of these types of heterogeneous interventions is a global concern (Simonet et al., 2018a; Duchelle et al., 2018a).

The incentives, disincentives and enabling measures to offset deforestation have produced mixed results in terms of household and community well-being in different local level REDD+ project sites, located in different countries (Atela et al., 2015). As concerns positive results, PES have contributed to poverty reduction among others in Mexico (Alix-Garcia, Sims \& Yañez-Pagans, 2015) improved well-being in project sites in Uganda (Jayachandran et al., 2017), improve well-being as indicated by the results from the analysis of 23 countries (Sunderlin et al., 2014a). For the case of negative results or no impacts, evidence of inequality and elite capture in benefit sharing was reported in Madagascar (Poudyal et al., 2018; Poudyal et al., 2016), community perception on limited or no impact on local income recorded in local REDD+ initiatives e.g., in Tanzania (Svarstad \& Benjaminsen, 2017) and Kenya (Atela et al., 2015). These are clear indications that the results expected from REDD+ projects and programs will depend on how the aspects of effectiveness, equity and efficiency are taking into consideration during project and program design and implementation while at the same time combining suitable mix of incentives, enabling measures and disincentive interventions that are sensitive to the household and community context (Duchelle et al., 2018a). This is important because a project model dominated by donor or development support could find it difficult to avoid leakage, manage transaction cost, and ensure permanence and to deliver non-carbon benefits (Vatn \& Vedeld, 2011). Careful and skillful analysis of the drivers of deforestation, community and stakeholder consultations are necessary during the feasibility study phase of forest carbon emission reduction projects and programs to ensure that separate and context specific approaches and control systems are put in place for community benefit (Vatn \& Vedeld, 2011).

\subsection{Suitability of REDD+ Project Location}

This section presents and analyses the opinions and perspectives of stakeholders on the project locations with regard to the suitable factors of REDD+ project locations.

\subsubsection{Stakeholder's Perception on Deforestation Threat and Opportunity Cost in Project Sites}

Regarding the importance of deforestation threat to determine the location of REDD+ projects, on average almost all $(95 \%)$ respondents had the same opinion pointing to the fact that high deforestation threat factor is important. Using low deforestation rates to set reference levels in projects, will deliver less carbon emission reductions when compared to chosen reference levels (Pasgaard \& Mertz, 2016). Following the deforestation threat determinant, respondents expressed satisfaction (98\%) with the location of ongoing REDD+ projects. Determining reference levels based on deforestation threats was a challenging task during the feasibility study process of the case study projects. During the feasibility studies, there was confusion in distinguishing between project area and reference area in some cases, and doubts casted on the robustness of the approach in most of the calculations and analysis in terms of baseline and project emission scenarios, using historical deforestation rates as reference points. It should be noted that setting the right forest emission reference level is an issue that the REDD+ process in general is 
struggling to grapple with in Cameroon. However, while waiting for clear national guidelines, projects are advised to use any methodology of their choice, provided they are well applied and presented.

Stakeholders did not see opportunity cost as a determining factor that needs to be taking into consideration when selecting locations for projects that are expected to deliver effective carbon and livelihood results. On average, $80 \%$ of respondent noted that opportunity cost is not important for making a choice on project location. This is as oppose to very few opinions $19 \%$ that considered opportunity cost to be important, for selecting project location. Further discussions with respondents indicated that, there is lack of understanding on the importance and implications of the opportunity cost variable in REDD + project outcomes. Tackling deforestation drivers with high opportunity costs are often challenging for land users (Pasgaard \& Mertz, 2016). Low opportunity cost is an important determinant for local willingness to engage in REDD+ activities (Pasgaard \& Mertz, 2016)., since at the local level, activities of poor households form a greater share of unplanned deforestation activities (Brimont, 2014).

\subsubsection{Stakeholders Perception of Local Population Willingness and Size of Forest Areas}

The respondents generally agreed that the willingness of local population to participate and involve in REDD+ projects from design to implementation is important to be considered when making choice of REDD + project location. In terms of level of satisfaction of current project locations in relation to local willingness to involve, respondents agreed on average (86\%) that local communities in all project sites expressed willingness to be part of the REDD+ projects. These positive responses can be questioned because one of the authors who participated in the first quarter evaluation meeting, reported that project managers mentioned that some disagreement between communities and project proponents occurred in relation to the land allocated for reforestation, choice of tree species for reforestation and proposed fish smoking techniques. REDD + project managers of these sites attributed the situation to the insufficient consultations carried out during project feasibility analysis and project design. Disagreement between land users (agriculturalist and pastoralist) was also recorded for the case of the two projects in the Sudano-sahelian agroecological zone. Notwithstanding, project implementation continued after community sensitization and consultations were repeated, though with changes in some variables (for example shifts in the location of planned reforestation areas, choice of tree species etc.) as compared to initial project plan. Experience from REDD+ projects in the Brazilian amazon indicates that project sustainability was jeopardized as a result of the absence of long-term community participation in project activities (Cromberg, Duchelle \& Rocha, 2014).

Concerning the size of forest areas, the survey respondents agreed (89\%) that forest area size, especially the carbon accounting area is important in choosing a project site that will guarantee sufficient quantity of carbon credits. Respondents further had an opinion of satisfaction (91\%) with the current size of the carbon accounting areas of the case study projects. Balooni \& Lund (2014) note that small forest areas seem ill-suited to ensure sufficient emission reductions and may record high transaction cost due to their small-scale nature.

\subsubsection{Stakeholder Perception on Non-Carbon Benefits}

The survey respondents showed strong agreement $(71 \%)$ on the fact that non-carbon benefits are important in determining a project location. The reactions from the respondents showed a relatively strong confidence that current case study project sites have potentials to deliver non-carbon benefits. It should be noted that in Cameroon, it is required that REDD+ project feasibility studies demonstrate the capacity of project activities to deliver noncarbon benefits that are most of the time linked to community well-being, poverty reduction, improvement of access rights and local governance and biodiversity conservation etc. Nonetheless, there is lack of robust methodologies with clear quantifiable indicators to monitor and evaluate non-carbon benefits in current and future REDD+ projects in Cameroon. REDD+ projects that have been well designed and implemented were capable to deliver non-carbon benefits (Duchelle et al., 2018a).

\subsection{Latent Factors Driving Choice of Project Location in Cameroon}

Despite the fact that stakeholder opinions generally indicate that the REDD+ project locations satisfy the five suitability characteristics; other latent factors could have influenced the selection of sites for the different projects. It is argued that pre-existing interest and projects, capacity and experiences of the sponsoring organization and/or project proponent, their aim to secure continues funding for existing projects can influence the selection of a project location (Pasgaard, 2015). These are the same type of factors that contributed to the site selection of current REDD+ initiatives in Cameroon. The sponsor of the case study REDD+ projects - the National Participatory Development Program (NPDP) has interest and experience working with local councils toward local development, thus council areas were compulsory the areas targeted for selection irrespective of the suitability of other areas in terms of deforestation threat, local willingness to engage and forest size. These projects are being implemented as part of a component of the NPDP program that propels local development through decentralized entities, thus eliminating other forest areas under different forest management regimes, from the selection process. Furthermore, 
despite the fact that many local councils were involved in the selection process, council areas without NPDP supported council development plans were eliminated from the selection process (Alix-Garcia et al., 2015). There was also a need for the project area selection process to respect project distribution according to the agroecological zones in Cameroon, ensuring that all agroecological zones host at least a REDD+ project, irrespective of the desirable factors of project location. The councils acting as project proponents, selected areas with previous interest within their council spatial limits, such as existing forest reserve, council forest or planned council forest etc.

This same situation can also be observed in other areas in Cameroon were REDD+ project ideas have been identified recently by some conservation organizations (World Wide Fund, Tri-National de la Sangha Foundation etc.), and national non-governmental organizations in which conservation experience, interest and the possibilities to mobilize financial resources appeared to be the major drivers of the choice of their project areas. From the analysis, having project locations that satisfy the combination of the 5 or more desirable characteristics could be challenging in practice. In this condition, REDD + project proponents are faced with the un-avoidable trade-offs between the multiple objectives of REDD+ that are expected to be achieved in a REDD+ project.

\section{Discussion and Conclusion}

This paper aimed to explore results-based determinants in local forest carbon initiatives so as to generate information and lessons that will contribute to shape the development of performance-based REDD + programs and projects, required by Cameroon to respond to a portion of its international climate commitments. The conceptual background draws on two types of determinants identified in literature - the kinds of instruments/interventions employed and the suitability of project location. Concerning the determinants related to the types of instruments, findings indicate that case study projects employed a combination of incentives, disincentives and enabling measures towards achieving REDD+ outcomes. However, none of the projects proposed conditional incentives (direct payments) to land owners and users, the key innovation brought by REDD+. This can be due to the fact that these projects had their start-up funding through development aid and since then, they have not been able to secure additional financial resources. None of these projects have made attempts towards valorizing carbon credits, for example through voluntary carbon standards where the prime objective is about results.

There is no indication if the objective of generating lessons learned from these projects will be achieved, especially on how to operationalize conditional payments, and to evaluate the impacts of REDD+ payments on carbon and livelihoods. Lessons are important since choosing the suitable payment system should be based on tested models. Shrestha et al. (2017) reported social tension that occurred between households in a community in Nepal as a result of a faulty payment distribution system. Providing incentives through direct payment to land owners and users is a component that needs to be included and tested in future/planned REDD+ projects and programs in Cameroon. Furthermore, without conditional incentives, there is limited guarantee on the effectiveness of projects, in the medium and long-term in terms of avoiding leakage, permanence and the delivery of non-carbon benefits. At the same time this paper is not downplaying the role of the other types of instruments and interventions in supporting the efforts towards effective results in REDD + projects.

Having instruments/interventions in place for a project to guarantee effective results will depend if a project is located in a desirable location. The criteria for selecting project location are always appreciated and validated by stakeholders during project identification and feasibility study phases and this raises the issue of the technical capacity of stakeholders to assess the selection criteria. In this analysis, stakeholders' opinion related to project locations pointed strongly that case study project locations were suitable in terms of deforestation threat, local willingness to engage, forest size and non-carbon benefit potentials. However, the narrative from stakeholders' opinion could have been different if stakeholders had proper understanding of the concepts and their implication on project long-term outcomes. Based on the fact that feasibility study reports are validated by stakeholders after consultations, it is important for these stakeholders to have a certain level of capacity to be able to provide useful contributions and judgements that will aid overall project design and implementation. In this context, continuous capacity building is an aspect to be considered seriously in the REDD+ process in Cameroon.

Results also indicated that other hidden factors influenced the choice of project locations such as pre-existing interest and experience of the project proponents. This study is further indicating the complexity of designing REDD+ projects in a real-world situation i.e., having both a whole series of instruments/ interventions and a suitable project location in order to guarantee results. In this context good choices have to be made and proper orientations given during the project design phase, to avoid a situation where the national territory is covered extensively with an increasing number of REDD+ branded projects with limited or no contribution to effective carbon emission reductions when compared to the long-term national emission reductions balance sheet. 


\section{Acknowledgements}

The paper was supported by the GIZ Forest-Environment Program (GIZ/PFE) in Cameroon, PNDP Cameroon and FOKABS. The views expressed in this paper remain those of the authors and not of the donors or the affiliated organizations. The valuable suggestions and comments made by anonymous reviewers is gratefully acknowledged.

\section{References}

Alix-Garcia, J. M., Sims, K. R., \& Yañez-Pagans., P. (2015). Only one tree from each seed? Environmental effectiveness and poverty alleviation in Mexico's Payments for Ecosystem Services Program. American Economic Journal: Economic Policy, 7, 1-40. https://doi.org/10.1257/pol.20130139

Angelsen, A., Hermansen, E. A., Rajão, R., \& Van Der Hoff, R. (2018). Results-based payment: Who should be paid, and for what? Transforming REDD+: Lessons and new directions. Center for International Forestry Research (CIFOR), Bogor, Indonesia. 41-54.

Atela, J. O., Minang, P. A., Quinn, C. H., \& Duguma, L. A. (2015). Implementing REDD + at the local level: Assessing the key enablers for credible mitigation and sustainable livelihood outcomes. Journal of Environmental management, 157, 238-249. https://doi.org/10.1016/j.jenvman.2015.04.015

Balooni, K., \& Lund, J. F. (2014). Forest rights: the hard currency of REDD+. Conservation Letters, 7, 278-284. https://doi.org/10.1111/conl.12067

Bennett, N. J. (2016). Using perceptions as evidence to improve conservation and environmental management. Conservation Biology, 30, 582-592. https://doi.org/10.1111/cobi.12681

Börner, J., West, T., Blackman, A., Miteva, D., Sims, K., \& Wunder, S. (2018). National and subnational forest conservation policies: What works, what doesn't. Transforming REDD+: Lessons and new directions. Center for International Forestry Research (CIFOR), Bogor, Indonesia. 105-116.

Brimont, L. (2014). Le coût de la Réduction des Emissions issues de la Déforestation et de la Dégradation des forêts $(\mathrm{REDD}+)$ à Madagascar. Doctoral dissertation, AgroParisTech. Paris. France.

Carmenta, R., Zabala, A., Daeli, W., \& Phelps, J. (2017). Perceptions across scales of governance and the Indonesian peatland fires. Global Environmental Change, 46, 50-59. https://doi.org/10.1016/j.gloenvcha.2017.08.001

Cerbu, G. A., Swallow, B. M., \& Thompson, D. Y. (2011). Locating REDD: A global survey and analysis of REDD readiness and demonstration activities. Environmental Science \& Policy, 14, 168-180. https://doi.org/10.1016/j.envsci.2010.09.007

Chia, E. L., Hubert, D., Carudenuto, S., \& Sene, O. (2019). Evolution in the enabling factors for transformational change in forestry and land use policy processes: the case of REDD+ in Cameroon. International Forestry Review, 21(1), 62-72. https://doi.org/10.1505/146554819825863762

Cromberg, M., Duchelle, A., \& Rocha, I. (2014). Local participation in REDD+: lessons from the Eastern Brazilian Amazon. Forests, 5, 579-598. https://doi.org/10.3390/f5040579

De Sassi, C., Sunderlin, W. D., Sills, E. O., Duchelle, A. E., Ravikumar, A., Iap, R., .... Kweka, D. (2014). REDD+ on the ground: Global insights from local contexts. REDD+ on the ground: A case book of subnational initiatives across the globe. Center for International Forestry Research (CIFOR), Bogor, Indonesia. 420-439.

Duchelle, A. E., Simonet, G., Sunderlin, W. D., \& Wunder, S. (2018). What is REDD+ achieving on the ground? Current Opinion in Environmental Sustainability, 32, 134-140. https://doi.org/10.1016/j.cosust.2018.07.001

Duchelle, A., De Sassi, C., Sills, E., \& Wunder, S. (2018). People and communities: Well-being impacts of REDD+ on the ground. Transforming REDD+: Lessons and new directions. Center for International Forestry Research (CIFOR), Bogor, Indonesia. 131-141.

Duchelle, A., Seymour, F., Brockhaus, M., Angelsen, A., Larson, A., Moeliono, M., ... Martius, C. (2018). REDD+: Lessons from national and subnational implementation. World Resources Institute, Washington, DC, USA.18p.

Ezzine-De-Blas, D., Wunder, S., Ruiz-Pérez, M., \& Del Pilar Moreno-Sanchez, R. (2016). Global patterns in the implementation of payments for environmental services. PloS one, 11, e0149847. https://doi.org/10.1371/journal.pone.0149847

Hett, C., Heinimann, A., Epprecht, M., Messerli, P., \& Hurni, K. (2012). Carbon pools and poverty peaks in Lao PDR. Mountain Research and Development, 32, 390-400. https://doi.org/10.1659/MRD-JOURNAL-D-12- 
00065.1

Jayachandran, S., De Laat, J., Lambin, E. F., Stanton, C. Y., Audy, R., \& Thomas, N. E. (2017). Cash for carbon: A randomized trial of payments for ecosystem services to reduce deforestation. Science, 357, 267-273. https://doi.org/10.1126/science.aan0568

Katerere, Y., \& Kalame, F. B. (2015). Non-Carbon Benefits: The Key to Successful REDD+ Implementation in Africa. UNECA. Policy Brief No. 15.7p.

Mertz, O., Müllerb, D., Sikorc, T., Hettd, C., Heinimannd, A., Castellae, J.-C., ... Sunb, Z. (2012). The forgotten D: challenges of addressing forest degradation in complex mosaic landscapes under REDD. Geografisk Tidsskrift-Danish Journal of Geography, 112, 63-76.

MINEPDED. (2018). Cameroon National REDD+ Strategy. MINEPDED. Yaounde. Cameroon. 103p.

MINEPDED. Cameroon Readiness Preparatory Proposal (R-PP)'. (2012). Ministry of Environment, Nature Protection and Sustainable Development. Yaounde, Cameroon. $157 \mathrm{p}$.

Moss, N., \& Nussbaum, R. (2011). A Review of Three REDD+ Safeguard Initiatives. Forest Carbon Partnership Facility-FCPF and UN-REDD Programme. Retrieved January 20, 2019, from http://www.forestcarbonpartnership

Newton, P., Nichols, E. S., Endo, W., \& Peres, C. A. (2012). Consequences of actor level livelihood heterogeneity for additionality in a tropical forest payment for environmental services programme with an undifferentiated $\begin{array}{lllll}\text { reward structure. Global Environmental } & \text { Change, 22, }\end{array}$ https://doi.org/10.1016/j.gloenvcha.2011.10.006

Pandey, S. S., Cockfield, G., \& Maraseni, T. N. (2016). Assessing the roles of community forestry in climate change mitigation and adaptation: A case study from Nepal. Forest Ecology and Management, 360, 400-407. https://doi.org/10.1016/j.foreco.2015.09.040

Pasgaard, M. (2015). Lost in translation? How project actors shape REDD+ policy and outcomes in C ambodia. Asia Pacific Viewpoint, 56, 111-127.

Pasgaard, M., \& Mertz, O. (2016). Desirable qualities of REDD+ projects not considered in decisions of project locations. Environmental Research Letters, 11.

PNDP. (2017a). Feasibiity study report: Project for the reduction of deforestation and forest degradation in the Bangante-Bana-Bangou intercommunal massif forest. MINEPAT.PNDP. Yaounde, Cameroon.

PNDP. (2017b). Feasibiity study report: Project for the conservation of the Ouro Doukoudje massif forest and the reforestation of the west bank of lake Lagdo. MINEPAT.PNDP. Yaounde. Cameroon.

PNDP. (2017c). Feasibiity study report: Project to reduce the degradation and restoration of vegetation cover in the Pitoa Council agro-sylvo-pastoral area. MINEPAT.PNDP. Yaounde. Cameroon.

PNDP. (2017d). Feasibiity study report: Reduction of mangrove deforestation and degradation through integrated sustainable mangrove and associated coastal forest management in Tiko-Limbe III. MINEPAT.PNDP. Yaounde.

PNDP. (2017e). Feasibiity study report: Project for the integral protection of the Yoko communal forest through the implementation of agro-sylvo-pastoral activities. MINEPAT.PNDP. Yaounde. Cameroon.

PNDP. (2018a). Feasibiity study report : Protection de la zone boisée de Lokoti dans la Commune de Meiganga à travers l'adoption des activités alternatives dans les zones périphériques MINEPAT.PNDP. Yaounde. Cameroon.

PNDP. (2018b). Rapport sur la capitalisation des résultats / acquis de la composante REDD+ du programme national de développement participatif (PNDP). MINEPAT, PNDP, Yaoundé. Cameroon.

Poffenberger, M. (2015). Restoring and conserving Khasi forests: A community-based REDD strategy from northeast India. Forests, 6, 4477-4494.

Poudyal, M., Jones, J. P., Rakotonarivo, O. S., Hockley, N., Gibbons, J. M., Mandimbiniaina, R., ... Ramamonjisoa, B. S. (2018). Who bears the cost of forest conservation? PeerJ., 6, e5106. https://doi.org 10.7717/peerj.5106

Poudyal, M., Ramamonjisoa, B. S., Hockley, N., Rakotonarivo, O. S., Gibbons, J. M., Mandimbiniaina, R., ... Jones, J. P. (2016). Can REDD+ social safeguards reach the 'right'people? Lessons from Madagascar. Global Environmental Change, 37, 31-42. 
Salzman, J., Bennett, G., Carroll, N., Goldstein, A., \& Jenkins, M. (2018). The global status and trends of payments for ecosystem services. Nature Sustainability, 1, 136.

Shrestha, S., Shrestha, U. B., \& Bawa, K. S. (2017). Contribution of REDD+ payments to the economy of rural households in Nepal. Applied geography, 88, 151-160.

Simonet, G., Bos, A., Duchelle, A. E., Resosudarmo, I. A. P., Subervie, J., \& Wunder, S. (2018). Forests and carbon: The impacts of local REDD+ initiatives. Transforming REDD+: Lessons and new directions. Center for International Forestry Research (CIFOR), Bogor, Indonesia. 117-130.

Simonet, G., Subervie, J., Ezzine-De-Blas, D., Cromberg, M., \& Duchelle, A. E. (2018). Effectiveness of a REDD+ Project in Reducing Deforestation in the Brazilian Amazon. American Journal of Agricultural Economics, $101,211-229$.

Sunderlin, W. D., Ekaputri, A. D., Sills, E. O., Duchelle, A. E., Kweka, D., Diprose, R., ... Enright, A. (2014). The challenge of establishing REDD+ on the ground: Insights from 23 subnational initiatives in six countries, CIFOR, Bogor, Indonesia. 56p.

Sunderlin, W. D., Larson, A. M., Duchelle, A. E., Resosudarmo, I. A. P., Huynh, T. B., Awono, A., \& Dokken, T. (2014). How are REDD + proponents addressing tenure problems? Evidence from Brazil, Cameroon, Tanzania, Indonesia, and Vietnam. World Development, 55, 37-52. https://doi.org/10.1016/j.worlddev.2013.01.013

Svarstad, H., \& Benjaminsen, T. A. (2017). Nothing succeeds like success narratives: a case of conservation and development in the time of REDD. Journal of Eastern African Studies, 11, 482-505.

UNFCCC. (2011). The Cancun Agreements: Outcome of the Work of the ad hoc Working Group on Long-Term Cooperation under the Convention Decision 1/CP.16; Report of the Conference of Parties on Its Sixteenth Session, Cancun, Mexico, 29 November-10 December 2010; FCC/CP/2010/7 Add 1; United Nations Framework Convention on Climate Change: Bonn, Germany.

UNFCCC. (2015). The Paris Agreement. UNFCCC. 27p.

Vatn, A., \& Vedeld, P. (2011). Getting ready! A study of national governance structures for REDD+. Noragric Report. Norway.

\section{Copyrights}

Copyright for this article is retained by the author(s), with first publication rights granted to the journal.

This is an open-access article distributed under the terms and conditions of the Creative Commons Attribution license (http://creativecommons.org/licenses/by/4.0/). 